УАK 338.33:631.11:005.332.4

\title{
А. А. Чикуркова,
}

А. е. н., професор, завідувач кафедри менеджменту, публічного управління

та аАміністрування, Подільський Аержавний аграрно-технічний університет,

м. Кам'янець-Подільський

ORCID ID: 0000-0003-2978-3961

B. B. Юр'єв,

аспірант, Подільський державний аграрно-технічний університет, м. Кам'янець-Подільський ORCID ID: 0000-0002-8673-849X

DOI: $10.32702 / 2306-6792.2021 .21 .80$

\section{ТЕОРЕТИЧНІ АСПЕКТИ РОЗВИТКУ АИВЕРСИФІКАЦЇ̈ АІЯЛЬНОСТІ СІЛЬСЬКОГОСПОААРСЬКИХ ПІАПРИЕМСТВ}

\author{
A. Chykurkova, \\ Doctor of Economic Sciences, Professor, Head of the Department of Management, Public Management \\ and Administration, State Agrarian and Engineering University in Podilya, Kamianets-Podilskyi \\ V. Yurev, \\ Postgraduate student, State Agrarian and Engineering University in Podilya, Kamianets-Podilskyi, Ukraine
}

\section{THEORETICAL ASPECTS OF THE DEVELOPMENT OF DIVERSIFICATION OF AGRICULTURAL ENTERPRISES}

Статтю присвячено дослідженню теоретичних положень диверсифікації діяльності як процесу оновлення номенклатури, асортименту продукції, робіт та послуг, освоєння нових сегментів ринку, Ажерел і напрямів інвестування, удосконалення маркетингової діяльності як засобу зростання конкурентоспроможності підприємства. Розкрито поняття Аиверсифікації діяльності як стратегії забезпечення конкурентоспроможного розвитку, яка передбачає впровадження організаційно-економічних і правових змін на сільськогосподарських підприємствах. За результатами дослідження виявлено, що до причин диверсифікації діяльності сільськогосподарського підприємства можна віднести: розвиток науково-технічного прогресу; зростання конкуренції на внутрішніх і зовнішніх ринках внаслідок заповнення ринків; відсутність перспективи зростання прибутків в основній сфері діяльності, що пов'язано з із вимогами агротехнологій і обмеженістю земельних ресурсів. Надзвичайно швидкі зміни ділового середовища українських сільськогосподарських підприємств, пов'язані з розвитком конкуренції, нових інформаційних технологій, глобалізацією бізнесу та іншими факторами, обумовили зростання важдивості диверсифікації їх Аіяльності. В умовах жорсткої конкурентної боротьби і посилення впливу змін, які відбуваються у зовнішньому середовищі, організації мають концентрувати увагу не тільки на внутрішньому стані справ, а й виявляти та враховувати у своїй діяльності можливі зміни оточення. При цьому основною залишається проблема збалансування внутрішніх можливостей організації та змін у зовнішньому середовищі 3 метою виживання у конкурентній боротьбі сьогодні й у перспективі. Визначено, що диверсифікація діяльності сільськогосподарських підприємств полягає в підтримці і розвитку процесу виробництва, інтелектуального потенціалу співробітників фірми, у підвищенні асортименту і якості товарів, що виробляються, в освоєнні нових ринків, збільшенні збуту i, нарешті, в підвищенні ефективності діяльності.

,The article is devoted to the study of theoretical provisions of diversification as a process of updating the range, range of products, works and services, development of new market segments, sources and areas of investment, improving marketing activities as a means of increasing the competitiveness of the enterprise. The concept of diversification of activity as a strategy to ensure competitive development, which involves the introduction of organizational, economic and legal changes in agricultural enterprises. The results of the study revealed that the reasons for the diversification of the agricultural enterprise include: the development of scientific and technological progress; increasing competition in domestic and foreign markets due to the filling of markets; lack of prospects for revenue growth in the main field of activity, which is due to the requirements of agricultural technology and limited land resources. Extremely rapid changes in the business environment of Ukrainian agricultural enterprises, related to the development of competition, new information technologies, globalization of business and other factors, have led to the growing importance of diversification of their activities. In conditions of fierce competition and increasing the impact of changes that occur in the external environment, organizations must focus not only on the internal state of affairs, but also to identify and take into account possible changes in the environment.

At the same time, the main problem remains balancing the internal capabilities of the organization and changes in the external environment in order to survive in the competition today and in the future. It is determined that the diversification of agricultural enterprises is to support and develop the production process, the intellectual potential of employees, to improve the range and quality of goods produced, to develop new markets, increase sales and, finally, to increase efficiency. It is determined that it is important when choosing areas of diversification of agricultural enterprises to take into account the specific features of the agricultural sector of the economy, which in science include: 1) attachment of agricultural activities 
to the main means of land production, which is regarded as a spatial factor; 2) the intertwining of agricultural production with natural processes beyond its control; 3 ) the dependence of agriculture on the use of biological factors, which determines the continuity of the production process; 4 ) territorial dispersion of agriculture, implementation of agricultural production on large areas; 5 ) lower level of economic efficiency of agricultural production in comparison with industry; 6) conservatism and inelasticity of agriculture, untimely monitoring and response to changes in market conditions; 7 ) mismatch of prices for agricultural products and prices for resources required for its production, the need for the formation of food stocks.

Ключові слова: диверсифікачія, розвиток, номенклатура, асортимент, зміни, ефективність. Keywords: diversification, development, nomenclature, assortment, changes, efficiency.

\section{ПОСТАНОВКА ПРОБЛЕМИ}

3-поміж основних теоретичних і прикладних проблем забезпечення конкурентоспроможності сільськогосподарських підприємств є розвиток диверсифікації їх діяльності. Ефективність роботи сільськогосподарських підприємств буде залежати від того, наскільки правильно керівництво зможе спрогнозувати розвиток підприємства в перспективі, оцінити ринки збуту продукції своїх конкурентів, забезпечити конкурентоспроможність продукції, врахувати негативні фактори, оцінити підприємницький ризик і передбачити шляхи ефективних дій. Одним із найбільш ефективних інструментів вирішення цього завдання доцільно вважати диверсифікацію. В Україні поглиблюється криза в економіці, яка торкнулася і сільськогосподарських підприємств. Майже всі галузі виробництва не мають сприятливих передумов глибокої якісної перебудови. Значних якісних змін сільськогосподарські підприємства мають можливість зазнати завдяки впровадженню диверсифікації ї діяльності. Узагальнення та розвиток теоретичних засад диверсифікації діяльності сільськогосподарських підприємств як важливий напрям забезпечення їх конкурентоспроможного розвитку є вкрай важливою проблемою.

\section{АНАЛІЗ ОСТАННІХ ДОСЛІДЖЕНЬ I ПУБЛІКАЦІЙ}

Теоретичні основи диверсифікації діяльності як процесу оновлення номенклатури, асортименту продукції, робіт та послуг, освоєння нових сегментів ринку, джерел і напрямів інвестування, удосконалення маркетингової діяльності як засобу зростання конкурентоспроможності підприємства, закладені в роботах таких науковців: В. Андрійчук [1], I. Ансофф [2], К. Бері [23], А. Богатової [4], М. Горт [24], А. Грабович [6], О. Згурська [7; 8], М. Ільчук [13], М. Малік [16], М. Портер [25], В. Ткачук [20], А. Томпсон, А. Стрикленд [21] та інших. Науково-теоретичні аспекти диверсифікації як стратегії забезпечення конкурентоспроможного розвитку, яка передбачає впровадження організаційно-економічних і правових змін на сільськогосподарських підприємствах, досліджуються в роботах М. Багорка [3], Збарського [7], С. Ілляшенко [12], Ф. Котлера [14], В. Міщенка [15], О. Цогли [21] та інших.

Разом 3 тим, враховуючи вагомий внесок провідних зарубіжних та вітчизняних науковців у розв'язанні проблем диверсифікації діяльності підприємств, залишаються ще досі нерозкритими окремі питання. Зокрема, ринкові умови господарювання передбачають активне й широке використання різноманітних форм i методів впливу на всю низку процесів формування й забезпечення виробництва високоякісної та конкурентоспроможної продукції. Формами та методами економічного впливу на ці процеси є передовсім запровадження диверсифікації діяльності, визначення прийнятних Аля виробників її видів, узагальнення теоретичних і практичних засад реалізації диверсифікації в окремих сферах аграрного сектору економіки, дослідження потенційних переваг та недоліків диверсифікації діяльності з огляду на розв'язання соціально-економічних проблем сільськогосподарських підприємств. Усе це зумовило актуальність обраної теми дослідження, його мету і завдання.

\section{ПОСТАНОВКА ЗАВДАННЯ}

Враховуючи актуальність і потребу у подальшому розвитку теоретичних і практичних положень зазначеної проблематики, можна сформулювати завдання дослідження, яке полягає в узагальненні та удосконаленні теоретичних засад диверсифікації діяльності сільськогосподарських підприємств як пріоритетного напряму забезпечення їх конкурентоспроможного розвитку.

\section{ВИКЛАД ОСНОВНОГО МАТЕРІАЛУ ДОСЛІДЖЕННЯ}

Американський економіст А. Чандлер є автором теорії розвитку диверсифікації діяльності підприємств [26]. М. Портер та інші послідовники розвинули цю теорію та створили науковометодичний базис для реалізації даної теорії у практичну діяльність підприємств. У сучасній 
літературі диверсифікацію у вузькому розумінні трактують як впровадження багатогалузевого виробництва 3 широкою номенклатурою та асортиментом продукції, робіт, послуг [23].

Під диверсифікацією розуміють процес формування багатогалузевої виробничої діяльності підприємств, що передбачає одночасне функціонування невзаємопов'язаних між собою видів виробництв, збільшення номенклатури та асортименту продукції на одному підприємстві. Це дає змогу перетворювати виробничі підприємства на складні багатоцільові комплекси, що виробляють різнорідну продукцію або надають послуги різного призначення і характеру [1; 6]. Аиверсифікація - це процес, який забезпечує зростання техніко-технологічного рівня виробництва, впровадження сучасних форм і методів організації виробництва та управління ним, удосконалення методів технічного контролю, покращення якості проАукції, посилення мотивація праці, активізацію людського фактору, створення конкурентоспроможної продукції [11, с. 18].

Стратегія диверсифікації означає, що підприємство розширює номенклатуру своєї продукції і виступає 3 новими товарами на нових ринках, освоює суміжні галузі виробництва. Аиверсифікація може мати різні форми. Широко застосовується така її форма, як освоєння нової продукції, яка за технологією виробництва, експлуатаційним призначенням чи обслуговуванням є дуже близькою до продукції, що вже виготовляється. Іноді диверсифікація набирає конгломеративної форми, коли освоюються нові вироби й галузі діяльності, які не мають зв'язку 3 діючим виробництвом. Така Аиверсифікація є організаційно складнішою. Аиверсифікація як стратегія виходу на ринок потребує великих витрат і має бути ретельно обгрунтованою. Вона під силу фінансове міцним підприємствам і застосовується передусім тоді, коли діяльність у межах однієї галузі виробництва починає обмежувати зростання обсягу продажу й розвиток підприємства. Аиверсифікація $є$ також засобом підвищення стійкості [15]. Аиверсифікація як стратегія переходу в інші сфери економічної діяльності є нагально необхідною, якщо ринок збуту підприємства суттєво скорочується [16].

Таким чином, більшість вчених вважають, що диверсифікація є стратегією забезпечення конкурентоспроможного розвитку підприємства (табл. 1).

Таким чином, на основі опрацювання літературних джерел [1-27] можна зробити висновок, що науковці розглядають поняття диверсифікації як: 1) стратегію конкурентоспроможного розвитку, за якої підприємство встановлює нові комерційні види діяльності з абсолютно новими продуктом та ринком збуту та розширює сфери діяльності своєї організаційної системи, незважаючи на те, до якого сектору економіки вона належить і якому напряму віддає перевагу; 2) процес, який має на меті будь-яке об'єднання суб'єктів господарювання різних сфер економічної діяльності, об'єднання виробництв та створення багатоцільових комплексів, що виробляють різнорідну продукцію або надають послуги різного призначення і характеру на інноваційних засадах.

Узагальнюючи різні підходи, вважаємо, що термін "диверсифікація діяльності сільськогосподарського підприємства" доцільно визначати як процес, що охоплює стратегію забезпечення конкурентоспроможного розвитку, яка передбачає впровадження організаційно-економічних і правових змін на сільськогосподарських підприємствах.

Аослідження показали, що до причин диверсифікації діяльності сільськогосподарського підприємства можна віднести такі: глобалізація ринку; поширення інформаційних технологій та комп'ютерної мережі; нові якості робочої сили, зайнятої в організаціях; укрупнення підприємств завдяки багатопрофільному характеру діяльності; розвиток науково-технічного прогресу; комунікації з іншими організаціями; загострення конкуренції на ринках внаслідок насичення ринків товарами; ринкові переваги підприємств, які оновлюють структуру виробництва [20, с. 14].

Аиверсифікація діяльності сільськогосподарського підприємства охоплює насамперед процеси, які передбачають зростання активності сільськогосподарських підприємств на диференційно географічному підгрунті світового ринку. Аиверсифікація діяльності сільськогосподарських підприємств відрізняється цілою низкою особливостей, зумовлених специфікою аграрного виробництва, і передбачає об'єднання основного виробництва сільськогосподарської продукції з переробкою, торгівлею, обслуговуванням, впровадженням товарів-новинок, товарів-замінників, а також освоєння нових сегментів ринку [6].

Розвиток диверсифікації діяльності сільськогосподарських підприємств також обумовлений такими причинами: необхідність виживання в умовах нестабільної ринкової економіки та кризових умовах, за рахунок збільшення видів підприємницької діяльності, які здатні утворити синергічний ефект, що дозволить забезпечити економічну стійкість підприємства; 
Таблиця 1. Трактування поняття "диверсифікація"

\begin{tabular}{|c|c|c|}
\hline $\begin{array}{l}№ \\
\text { 3/ח }\end{array}$ & Автор & Трактування \\
\hline 1 & А. Чандлер [26] & $\begin{array}{l}\text { Процес формування багатогалузевого виробництва з широкою номенклатурою та асортиментом } \\
\text { продукції, робіт, послуг }\end{array}$ \\
\hline 1 & $\begin{array}{l}\text { В. Андрійчук, } \\
\text { Т. Грабович }[1 ; 6]\end{array}$ & $\begin{array}{l}\text { Одна із суспільних форм організації виробництва, що передбачає проникнення фірм у нові для них сфери } \\
\text { діяльності, завдяки чому вони перетворюються на багатогалузеві комплекси. Акцент при цьому робиться } \\
\text { на створенні таких видів діяльності, які не пов'язані з основним виробництвом } \\
\end{array}$ \\
\hline 2 & I. Ансофф [2] & $\begin{array}{l}\text { Термін, що застосовується до процесу перерозподілу ресурсів, які існують на цьому підприємстві, в інші } \\
\text { сфери діяльності, що істотно відрізняються від попередніх» }\end{array}$ \\
\hline 3 & $\begin{array}{l}\text { М. Багорка, } \\
\text { I. Білоткач [3] }\end{array}$ & $\begin{array}{l}\text { Форма реалізації стратегії підприємства, яка передбачає його вихід на нові для підприємства сфери } \\
\text { бізнесу }\end{array}$ \\
\hline 4 & Д. Богатова [4] & $\begin{array}{l}\text { Диверсифікація діяльності є основою стратегічного розвиту агропромислового комплексу в цілому, що } \\
\text { дозволяє найбільш повно і раціонально використовувати свої ресурси та виробничий потенціал, } \\
\text { розширити асортимент та збільшити обсяги виробництва продукції }\end{array}$ \\
\hline 4 & $\begin{array}{l}\text { Великий } \\
\text { економічний } \\
\text { словник [5] }\end{array}$ & $\begin{array}{l}\text { 1. Розширення асортименту, зміна виду продукції, що виготовляється підприємством, фірмою, освоєння } \\
\text { нових видів виробництв з метою підвищення ефективності виробництва, отримання економічного зиску, } \\
\text { попередження банкрутства. } \\
\text { 2. Розподіл грошових капіталів, що вкладаються в економіку або використовуються в якості кредитів } \\
\text { поміж різними об’єктами з метою зниження ризику втрат та в надії отримати більший дохід» }\end{array}$ \\
\hline 5 & В. Збарський [7] & $\begin{array}{l}\text { Один із видів стратегії розвитку підприємництва, що передбачає певну поведінку на ринку, пов'язану з } \\
\text { експансією в нові географічні або галузеві сектори, обрання інших або додаткових видів діяльності } 3 \\
\text { метою оптимізації використання ресурсного потенціалу та мінімізації ризиків }\end{array}$ \\
\hline 6 & О. Згурська [8] & $\begin{array}{l}\text { Процес розширення підприємницької діяльності підприємств та одночасний розвиток різних, } \\
\text { невзаємопов'язаних видів виробництв, розширення номенклатури та асортименту вироблюваної } \\
\text { продукції в межах одного підприємства, в результаті чого виробництва перетворюються на складні } \\
\text { багатоцільові комплекси, що випускають продукцію або надають послуги різного призначення і } \\
\text { характеру. За своєю сутюю диверсифікація передбачає використання методу покращення діяльності } \\
\text { підприємства за новими напрямками з метою підвищення прибутку та використання своїх наявних } \\
\text { ресурсів з максимальню ефективністю }\end{array}$ \\
\hline 7 & О. Згурська [9] & $\begin{array}{l}\text { Процес оновлення (диференціація) товару і ринку одночасно, вихід за межі основного господарювання, } \\
\text { проникнення в нові галузі та сфери економіки }\end{array}$ \\
\hline 8 & $\begin{array}{l}\text { С. Ілляшенко, } \\
\text { Г. Пересадько [12] }\end{array}$ & $\begin{array}{l}\text { Процес входження (проникнення) в нові галузі діяльності, в яких суб’єкт господарювання ще не } \\
\text { господарював та які покликані змінити (замінити) або доповнити (розширити) асортимент продукції, що } \\
\text { вже випускається }\end{array}$ \\
\hline 9 & $\begin{array}{l}\text { М. Ільчук, } \\
\text { C. Нікітченко, } \\
\text { С. Перегуда [13] }\end{array}$ & $\begin{array}{l}\text { Об’єктивно необхідний процес розширення асортименту товарів та послуг, нових напрямів інвестування, } \\
\text { маркетингової діяльності з метою підвищення конкурентоспроможності підприємства, ефективності } \\
\text { діяльності, більш повного використання фінансових можливостей та ресурсів, зростання додаткової } \\
\text { вартості. } \\
\text { Зниження економічних ризиків та зростання доходів населення }\end{array}$ \\
\hline 10 & Ф. Котлер [14] & $\begin{array}{l}\text { Форма ефективного застосування накопиченого досвіду, а також засіб усунення недоліків } \\
\text { конкурентоспроможного функціонування }\end{array}$ \\
\hline 11 & А. Міщс & $\begin{array}{l}\text { Вид стратегії маркетингу, спрямованої на розширення сфер діяльності фірми на ринках нових продуктів, } \\
\text { виробництво яких не пов'язане із основним виробництвом компанії }\end{array}$ \\
\hline 12 & М. Малік [16] & $\begin{array}{l}\text { Розширення номенклатури та асортименту, зміна виду продукції, що виробляється підприємством, } \\
\text { освоєння нових видів виробництв для підвищення ефективності виробництва, отримання економічної } \\
\text { вигоди, запобігання банкрутства з урахуванням екологічних та соціальних потреб населення }\end{array}$ \\
\hline 13 & О. Румянцева [19] & $\begin{array}{l}\text { Володіння найрізноманітнішими фінансовими активами, з кожним з яких пов'язані різні ризики, аби } \\
\text { знизити ступінь ризику портфеля в цілому; або загальна ділова практика, що спрямована на розширення } \\
\text { номенклатури товарів та послуг та (або) географічної території, аби розпилити ризик та знизити } \\
\text { залежність від циклічності бізнесу» }\end{array}$ \\
\hline 14 & В. Ткачук [20] & $\begin{array}{l}\text { Розвиток декількох невзаємопов’язаних або обслуговуючих виробництв, розробка нових видів товарів, } \\
\text { робіт, послуг на основі перерозподілу ресурсів, якими забезпечене дане підприємство в інші сфери, які } \\
\text { суттєво відрізняються від попередніх задля досягнення певної стратегічної мети }\end{array}$ \\
\hline 15 & $\begin{array}{l}\text { А. Томпсон, } \\
\text { А. Стрикленд [21] }\end{array}$ & $\begin{array}{l}\text { Розширення номенклатури товарів (послуг) підприємства за рахунок споріднених чи нових, які можуть } \\
\text { виготовлятися і збуватися з використанням існуючого потенціалу, а також розвиток діяльності фірми в } \\
\text { абсолютно нових для неї галузях }\end{array}$ \\
\hline 16 & О. Цогла [22] & $\begin{array}{l}\text { Процес, що охоплює організаційні, економічні, правові зміни на підприємствах та направлений на } \\
\text { підвищення ефективності виробництва, зниження кількості банкрутств, своєчасне реагування на зміни } \\
\text { економічної кон'юнктури ринку для забезпечення прибутковості на основі використання ринкових } \\
\text { шансів і встановлення конкурентних переваг, зміцнення положення підприємства в ринковому сегменті }\end{array}$ \\
\hline 17 & К. Бері [23] & Збільшення кількості галузей, в яких функціонує компанія \\
\hline 18 & М. Горт [24] & Одночасне обслуговування компанією декількох ринків \\
\hline 19 & М. Портер [25] & $\begin{array}{l}\text { Одночасний розвиток багатьох не пов'язаних один з одним виробництв та розширенні товарного } \\
\text { асортименту }\end{array}$ \\
\hline
\end{tabular}

Ажерело: систематизовано автором на основі [1-27].

можливість підвищення зайнятості населення та збільшення робочих місць у сільськогосподарській сфері, що дасть можливість отримання стабільних сімейних доходів в умовах сезон- ності та традиційних сільськогосподарських робіт; повне використання ресурсів (як земельних, так і мобільних та стаціонарних електромашин) [4]. 
Під час дослідження диверсифікації діяльності сільськогосподарських підприємств в економічній науці $є$ різні підходи та критерії класифікації їі видів. Так, за першим виокремлюються такі види диверсифікації діяльності сільськогосподарського підприємства:

1) залежно від зв'язаності із сільськогосподарською діяльністю - зв'язана та незв'язана; 2) за стійкістю на агропродовольчому ринку економічна та соціально-орієнтована; 3) залежно від ризиковості - помірна, значна, інтенсивна; 4) за фінансовими можливостями - горизонтальна, вертикальна; 5) за державним регулюванням - програмна, цільова; 6) за географічно-територіальною належністю - міжнародна, регіональна, обласна, районна; 7) за структуризованістю - конгломератна, концентрична; 8) за рівнем невизначеності - випадкова, супутня [19].

За другим підходом науковці поділяють диверсифікацію діяльності сільськогосподарських підприємств на: 1) концентричну - утворення нової продукції зі своїх матеріалів; 2) вертикальну - випуск продукції, яку раніше одержували від постачальників; 3) горизонтальну - випуск продукції, що потребує нововведень і змін існуючих технологій; 4) корпоративну - утворення принципово нової продукції" [20].

Третій підхід, на нашу думку, є найбільш вдалим та передбачає поділ диверсифікації діяльності сільськогосподарського підприємства на галузеву і продуктово-асортиментну. При цьому галузева диверсифікація пов'язана із збільшенням сукупності функціонуючих на підприємстві галузей, які на стадії виробництва всіх видів сільськогосподарської продукції (для кінцевого споживання, проміжної (насіння, корми) і сировини для промислової переробки) технологічно не пов'язані між собою. Застосування такого виду диверсифікації доцільно тоді, коли підприємство починає розвивати нові для себе виробництва, що відрізняються від виробництв інших галузей кінцевим продуктом, застосовуваними засобами виробництва, його технологією та організацією [21].

Важливо при виборі напрямів диверсифікації діяльності сільськогосподарських підприємств враховувати специфічні особливості аграрного сектору економіки, до яких у науці відносяться: 1) прив'язаність сільськогосподарської діяльності до головного засобу виробництва землі, яка розцінюється як просторовий фактор та одночасно предмет і засіб праці; 2) переплетення виробництва сільськогосподарської продукції з непідвладними йому при- родними процесами; 3) залежність сільського господарства від використання біологічних факторів, що зумовлює безперервність процесу виробництва продукції; 4) територіальна розосередженість сільського господарства, здійснення аграрного виробництва на великих площах; 5) більш низький рівень економічної ефективності агровиробництва у порівнянні 3 промисловістю; 6) консервативність та нееластичність сільського господарства, несвоєчасне відслідковування і реагування на зміни кон'юнктури ринку; 7) невідповідність цін на сільськогосподарську продукції та цін на ресурси, необхідних для їі виробництва, потреба у формуванні продовольчих запасів [22].

Аиверсифікація як організаційна форма виробництва має ряд переваг для підприємства, але вона має й певні недоліки.

Ао переваг диверсифікації діяльності сільськогосподарського підприємства слід віднести:

1) ресурсні конкурентні переваги, ефективне залучення та використання власних ресурсів;

2) технологічні конкурентні переваги, використання технологій масового виробництва;

3) можливість отримання синергічного ефекту та збільшити ефективність;

4) збільшити збут продукції, шляхом залучення нових споживачів;

5) оновлення номенклатури і асортименту;

6) забезпечення економічної та продовольчої безпеки держави;

7) партнерські конкурентні переваги, формування соціальних, економічних стандартів господарської діяльності та їх реалізацією);

8) зменшення ризикованості діяльності.

Ао проблемних питань впровадження стратегії диверсифікації можна віднести:

1) недосконале вивчення особливостей нового ринку, можливі проблеми із пошуком та залучення джерел фінансування,

2) невизначеність часу впровадження;

3) не завжди дає змогу використати переваги спеціалізованого виробництва;

4) збільшення ризиків у випадку невдалого вибору стратегії диверсифікації та підтримки неперспективного виробництва;

5) диверсифікацію недоцільно застосувати на підприємствах 3 низьким рівнем концепції виробництва; можливе ускладнення управлінням підрозділами на великих агропідприємствах $[4 ; 8 ; 9 ; 25]$.

Отже, перевагами диверсифікації діяльності сільськогосподарських підприємств є: гнучкість, адаптованість до кон'юнктурних коливань, розширення асортименту продукції, зростання прибутку, зниження витрат на збут, 
економія від масштабу, розподіл фінансових ризиків за різними напрямами, полегшення виходу на світовий ринок, оптимізація структури і розмірів виробництва. Недоліками диверсифікації діяльності сільськогосподарських підприємства є: великі витрати на вхід у галузь та вихід із галузі у разі невдачі, для отримання прибутків потрібний час, брак знань і навичок управлінського персоналу, високий рівень ризику, неможливість точної оцінки перспективи диверсифікації, монополізація економіки.

\section{ВИСНОВКИ З ПРОВЕДЕНОГО ДОСЛІДЖЕННЯ}

На основі проведеного дослідження ми можемо зробити висновок, що поняття диверсифікації надзвичайно багатогранне та ще не отримало єдиного визначення. Вчені розглядають його з різних сторін, адже не можна не зважати на постійний розвиток суспільства та підприємництва. Підсумовуючи усі проаналізовані визначення, сформулюємо власне визначення: диверсифікація - це не лише зміна асортименту продукції, що випускається, але й повна переорієнтація ринків збуту, розподілення ризиків та зниження залежності від циклічності бізнесу й впливу факторів бізнес-середовища. Саме тому дослідження цього напряму все ще $є$ актуальним та перспективним. Ао напрямів подальшого дослідження диверсифікації можна віднести розробку практичних рекомендацій щодо розвитку диверсифікації виробничої діяльності сільськогосподарських підприємств у невиробничу сферу.

$\Lambda$ ітература:

1. Андрійчук В.Г. Ефективність діяльності сільськогосподарських підприємств: теорія, методика, аналіз. К.: КНЕУ, 2005. 292 с.

2. Ансофф І.В. Новая корпоративная стратегия. Питер Ком. 2008. 416 с.

3. Багорка М.О., Білоткач I.А. Аиверсифікація як фактор підвищення ефективності діяльності підприємств в сучасних умовах. Інвестиції: практика та досвід. 2009. № 10. С. 17-21.

4. Богатова А.Р.Аиверсифікація як чинник конкурентоспроможності аграрного підприємства. Ефективна економіка. 2018. № 10. Режим доступу: http://www.economy.nayka.com.ua/ ?op $=1 \& \mathrm{z}=6624$

5. Большой экономический словарь / Под ред. А.Н. Азрилияна. М.: Институт новой экономики. 2005.735 с.

6. Грабович Т.С.Аиверсифікація як мождивий напрям зростання промислового підприємства. Вісник НТУ "XПI". 2012. № 58 URL: http://www.kpi.kharkov.ua/archive
7. Збарський В.К.Теоретичні засади диверсифікації економічної діяльності фермерських господарств. Економіка АПК. 2016. № 10. С. 17.

8. Згурська О.Аиверсифікація як метод підвищення економічної ефективності підприємства. Інвестиції: практика та досвід. 2018. № 13. C. $16-21$.

9. Згурська О. Визначення суті та значення дефініції "диверсифікація". Економіка та держава. 2019. № 12. Режим доступу: http:// www.economy.in.ua/?op $=1 \& \mathrm{z}=4466 \& \mathrm{i}=13$

10. Економічна енциклопедія: У 3т. Ред. кол.: С.В. Мочерний (відпр. ред.) К.: ВУ Академія. 2002. C. 952.

11. Івченко $\Lambda$. Аиверсифікація діяльності підприємств як чинник їх економічного зростання. Інститут бухгалтерського обліку, контроль та аналіз в умовах глобалізації. Міжнародний збірник наукових праць. Вип. 1. 2016. Міжнародний збірник наук. праць. 2016. № 1. С. 101.

12. Ілляшенко С.М., Пересадько Г.О. Системний аналіз поглядів різних вчених на стратегію диверсифікації. Вісник Сумського національного аграрного університету. Серія: Економіка та менеджмент. 2008 № 4 (28). С. 3-8.

13. Ільчук М.M., Нікітченко С.О., Перегуда С.Ф. Аиверсифікація діяльності підприємницьких структур аграрної сфери. Економіка АПК. 2016. № 4. С. 13-20.

14. Котлер Ф. Основы маркетинга / [Пер. с англ. Е.М. Пеньковой]. М.: Прогресс, 1990.736 с.

15. Мищенко А.П. Стратегическое управление. Анепропетровск, 2003. 250 с.

16. Малік М. Й. Актуальні питання диверсифікації виробництва в аграрній сфері. Ефективна економіка. 2012. № 12.

17. Макаренко М.В. Технологія управління міжнародною конкуренспроможністю підприємств. Актуальні проблеми економіки. 2010. № 4. C. 114.

18. Панюк Т.П. Аиверсифікація як основа структурної модернізації економічної діяльності аграрних підприємств. Економічний форум. 2016. № 1. С. 193.

19. Румянцева Е.Е. Новая экономическая энциклопедия. 3-е изд. М.: Инфра-М., 2008. 826 с.

20. Ткачук В.І. Аиверсифікація діяльності аграрних підприємств: теорія, методологія, практика: автореф. дис. на здобуття наук. ступеня Ара екон. наук: спец. 08.00.04 "Економіка та управління підприємствами". Аьвів, 2012.39 с.

21. Томсон А.А. Стрикленд А.Аж. Стратегический менеджмент. Искусство разработки и реализации стратеги. М.: Банки и биржи, ЮНИТИ. 1998. С. 576.

22. Цогла О.О. Формування конкурентних переваг підприємства шляхом диверсифікації 
його діяльності. Актуальні проблеми економіки. 2010. № 4. С. 109-115.

23. Berry C. H. Corporate growth and diversification. Journal of Law and Economics. 1971. № 14 . S. $371-16$.

24. Gort M. Diversification and Integration in American Industry. Princeton, NJ: Princeton University Press. 1962.365 p.

25. Porter M.E. Competitive Strategy: Techniques for Analyzing Industries and Competitors. New York: The Free Press. 1980. 628 p.

26. Chandler A. Scale and Scope: The Dynamics of Industrial Capitalism. Germany, 1990.580 p.

\section{References:}

1. Andrijchuk, V.H. (2005), Efektyvnist' diial'nosti sil's'kohospodars'kykh pidpryiemstv: teoriia, metodyka, analiz [The efficiency of agricultural enterprises: theory, methodology, analysis], KNEU, Kyiv, Ukraine.

2. Ansoff, I.V. (2008), Novaia korporatyvnaia stratehyia [New corporate strategy], Pyter Kom, St.Petersburg, Russia.

3. Bahorka, M.O. and Bilotkach, I.A. (2009), "Diversification as a factor in improving the efficiency of enterprises in modern conditions", Investytsii: praktyka ta dosvid, vol. 10, pp. 17-21.

4. Bogatova, D.R. (2018), "Diversification as a factor of competitiveness of agricultural enterprise", Efektyvna ekonomika, [Online], vol. 10, available at: http://www.economy.nayka.com.ua/ ?op $=1 \& z=6624$ (Accessed 05 Nov 2021).

5. Azrylyian, A.N. (2005), Bol'shoj ekonomycheskyj slovar' [Big Dictionary of Economics], Ynstytut novoj ekonomyky, Moscow, Russia.

6. Hrabovych, T.S. (2012), "Diversification as a possible direction of growth of an industrial enterprise", Visnyk NTU "KhPI", vol. 58, available at: http://www.kpi.kharkov.ua/archive (Accessed 05 Nov 2021).

7. Zbars'kyj, V.K. (2016), "Theoretical principles of diversification of economic activity of farms", Ekonomika APK, vol. 10, pp. 17.

8. Zhurska, O. (2018), "Diversification as a method of improvement of economic efficiency of an enterprise", Investytsiyi: praktyka ta dosvid, vol. 13, pp. 16-21.

9. Zgurska, O. (2019), "Defining the essence and meaning of the definition of "diversification"", Ekonomika ta derzhava, vol. 12, pp. 77-82.

10. Mochernyj, S.V. (2002), Ekonomichna entsyklopediia [Economic Encyclopedia], Akademiia, Kyiv, Ukraine.

11. Ivchenko, L. (2016), "Diversification of enterprises as a factor in their economic growth", Mizhnarodnyj zbirnyk nauk. prats', vol. 1, pp. 101.
12. Illiashenko, S.M. and Peresad'ko, H.O. (2008), "Systematic analysis of the views of various scientists on the strategy of diversification", Visnyk Sums'koho natsional'noho ahrarnoho universytetu. Seriia: Ekonomika ta menedzhment, vol. 4 (28), pp. 3-8.

13. Il'chuk, M.M. Nikitchenko, S.O. and Perehuda, S.F. (2016), "Diversification of business structures of the agricultural sector", Ekonomika APK, vol. 4, pp. 13-20.

14. Kotler, F. (1990), Osnovy marketynha [Marketing Basics], Prohress, Moscow, Russia.

15. Myschenko, A.P. (2003), Stratehycheskoe upravlenye [Strategic management], Dnepropetrovsk, Ukraine.

16. Malik, M.J. (2012), "Current issues of diversification of production in the agricultural sector", Efektyvna ekonomika, vol. 12.

17. Makarenko, M.V. (2010), "Technology management of international competitiveness of enterprises", Aktual'ni problemy ekonomiky, vol. 4, pp. 114.

18. Paniuk, T.P. (2016), "Diversification as a basis for structural modernization of economic activity of agricultural enterprises", Ekonomichnyj forum, vol. 1, pp. 193.

19. Rumiantseva, E.E. (2008), Novaia ekonomycheskaia entsyklopedyia [New Economic Encyclopedia], Ynfra-M, Moscow, Russia.

20. Tkachuk, V.I. (2012), "Diversification of agricultural enterprises: theory, methodology, practice", Abstract of Ph.D. dissertation, Economy, Lviv, Ukraine.

21. Tomson, A.A. and Stryklend, A.Dzh. (1998), Stratehycheskyj menedzhment. Yskusstvo razrabotky y realyzatsyy stratehyy [Strategic management. The art of developing and implementing a strategy], Banky y byrzhy, YuNYTY, Moscow, Russia.

22. Tsohla, O.O. (2010), "Formation of competitive advantages of the enterprise by diversification of its activity", Aktual'ni problemy ekonomiky, vol. 4, pp. 109-115.

23. Berry, C.H. (1971), "Corporate Growth and Diversification", Journal of Law and Economics, vol. 14, no. 2, pp. 371-383.

24. Gort, M. (1962), Diversification and Integration in American Industry, Princeton University Press, Princeton, NJ.

25. Porter, M.E. (1980), Competitive Strategy: Techniques for Analyzing Industries and Competitors, The Free Press, New York, USA.

26. Chandler, A. (1990), Scale and Scope: The Dynamics of Industrial Capitalism, Germany.

Стаття надійшла до редакиії 10.11.2021 p. 